\title{
A inteligibilidade do desvio fonológico julgada por três grupos de julgadores $* * * *$
}

\author{
Intelligibility of phonological disorder assessed by three groups of \\ judges
}

Gabriele Donicht*

Karina Carlesso Pagliarin**

Helena Bolli Mota***

Márcia Keske-Soares***

*Fonoaudióloga. Doutoranda em Lingüística Aplicada pela Pontifícia Universidade Católica do Rio Grande do Sul (PUC-RS). Endereço para correspondência: Rua São Lucas, 58/ 201 - Porto Alegre - RS -

CEP 91420-540

(gabrieledonicht@yahoo.com.br).

**Fonoaudióloga. Mestranda em Distúrbios da Comunicação Humana pela Universidade Federal de Santa Maria. Professora Substituta do Curso de Fonoaudiologia da Universidade Federal de Santa Maria.

***Fonoaudióloga. Doutora em Lingüística Aplicada pela Pontifícia Universidade Católica do Rio Grande do Sul. Docente do Curso de Fonoaudiologia e do Programa de PósGraduação em Distúrbios da Comunicação Humana da Universidade Federal de Santa Maria.

*****Trabalho realizado no Centro de Estudos sobre Linguagem e Fala (Celf) da Universidade Federal de Santa Maria (UFSM).

Artigo Original de Pesquisa

Artigo Submetido a Avaliação por Pares

Conflito de Interesse: não

\begin{abstract}
Background: intelligibility of phonological disorder. Aim: to compare the intelligibility of phonological disorder analyzed by three distinct groups of judges. Method: the research consisted of two samples: one sample was composed by 30 individuals with phonological disorder (assessed individuals) and the other sample was composed by the judges (speech-language therapists, laypeople and mothers). The spontaneous speech of children (i.e. three narratives of logical sequences) was analyzed by the different judges according to instructions given for intelligibility identification. For the data analysis, the mode of 90 sets of narratives was performed. The Kappa Concordance Analysis was then used to investigate statistical significance. Results: the statistical analysis indicates greater concordance between the judges for the end assessment possibilities (good and insufficient). Concordance among all judges was substantial in the identification of good intelligibility. Judgment of regular intelligibility was the most difficult. Conclusion: it was observed that the more unintelligible the speech, the more severe its classification by the groups of judges.
\end{abstract}

Key Words: Children; Phonological Disorder; Speech Intelligibility; Assessment.

\section{Resumo}

Tema: a inteligibilidade do desvio fonológico. Objetivo: comparar a inteligibilidade julgada do desvio fonológico a partir da análise de três grupos distintos de julgadores. Método: a pesquisa foi composta de duas amostras, uma amostra julgada (30 sujeitos com desvio fonológico) e outra julgadora (fonoaudiólogas, leigas e mães). Foi analisada a fala espontânea das crianças através da narração de três sequiências lógicas, as quais foram analisadas pelas julgadoras, acompanhadas por algumas questões para marcação da inteligibilidade. Para análise dos dados, foi realizada a MODA das 90 narrativas, possibilitando a análise estatística dos dados através da análise de concordância-Kappa. Resultados: a análise mostrou maior concordância entre os grupos de juízes para os extremos das possibilidades de julgamento (boa e insuficiente). A concordância entre todos os grupos de julgadores foi substancial para o julgamento da inteligibilidade boa sendo mais difícil o julgamento da inteligibilidade regular. Conclusão: observou-se que quanto mais foi julgada ininteligível a fala, mais severa foi a sua classificação pelos grupos de julgadores participantes. Palavras-Chave: Crianças; Distúrbio Fonológico; Inteligibilidade de Fala; Julgamento. 


\section{Introduction}

Speech intelligibility is the degree of clarity with which each emission is understood by most listeners 1 .

The speech of children with phonological disorder may lead to a limited phonetic inventory and a simplified phonologic system, which may result in an unintelligible speech, causing problems in communication. Therefore, social interaction may be impaired, as the disorder leads to a decrease in intelligibility 2.

The degree of speech intelligibility has important implications for therapeutic planning and for controlling the effectiveness of therapy in children with phonological disorder 3 . However, it is still difficult to measure intelligibility, since there are many variables that may influence it, such as knowledge of the context and experience of the listener with the speaker's "mistakes" 4.

Intelligibility is investigated in studies that consider different characteristics of the speaker, such as the case of children with hearing problems 5-7, children with problems in expressive speech 7 , and children with phonological disorder 2,4,8-10. However, studies that consider the perceptual analysis of intelligibility based on the assessment of different judges (mothers, speech therapists, laypeople) have not been found.

Thus, this study aimed at comparing the intelligibility of phonological disorder assessed by three different groups of judges.

\section{Methods}

The research

This study is characterized by its quantitative and transversal nature, and has two samples, one composed by the subjects to be assessed and the other composed by the judges. It was developed through the project "Correlation between Speech Intelligibility and the Degree of Severity of the Phonological Disorder based on the Analysis of Three Distinct Groups of Judges", registered under CEP No $106 / 05$.

\section{Participants}

The sample to be assessed consisted of 30 children diagnosed with phonological disorder, aged from $4: 1$ to $7: 11$, from which $20(66,7 \%)$ were boys and $10(33,3 \%)$ were girls. A specific authorization of the participants was requested to the parents, using the Term of Free and Informed Consent.

The other sample was composed by three groups of judges, which were: five women without daily contact with children with or without alterations in their speech, who did not know anything about the issue, called the group of "laypeople"; five speech therapists or undergraduate students of Speech Therapy, called the group of "speech therapists"; and five mothers of the subjects analyzed, which were called the group of "mothers". All the adult judges were native speakers of Brazilian Portuguese (BP), and were asked a specific authorization using the Term of Free and Informed Consent.

The speech therapists, just like the laypeople, were responsible for the higher education of five (100\%) participants. As for their marital status, five (100\%) of the laypeople were single, like most speech therapists $(80 \%)$, whereas four $(80 \%)$ mothers were married.

\section{Procedures}

The subjects underwent a speech evaluation (comprehensive and expressive language; stomatognathic system; articulatory examination), a phonological evaluation and an auditory one.

The phonological evaluation was done with the help of the pictures of the ABFW Test 11, which made it possible to obtain the linguistic sample of the children through exercises of naming and spontaneous speech. The data were recorded, phonetically transcribed and analyzed.

Based on contrastive analysis, the child's phonological system was determined, considering the criteria proposed by Bernhardt 12. After that, the Percentage of Consonants Correct (PCC) was calculated 13 .

After the evaluation of the PCC and the classification of the severity of the phonological disorder, it was found that most children in the research (13), which corresponds to $43,3 \%$, presented mild phonological disorder (10 boys and 3 girls). In the mild-moderate degree of phonological disorder there were $10(33,33 \%)$ subjects, who were five boys and five girls. Four subjects (three boys and one girl) presented a moderate-severe degree of phonological disorder, and three subjects (two boys and one girl) presented a severe degree.

In addition, a narrative test based on the thematic pictures taken from New Dimension in Text Production (Nova Dimensão em Produção de Textos) 14 was given to them, resulting in a sample of spontaneous speech that could be analyzed by 
the groups of judges. Three different logical sequences ("clown", "ball" and "duck"), with three pictures each, were used for the collection of the narratives. The stories narrated by the children were recorded, transcribed and edited, excluding possible interferences of the researcher during the narrations. The duration of all the narratives was standardized to 20 seconds each.

After editing the spontaneous narratives of the 30 children, the 90 narratives ( 3 per child) were randomly copied onto CDs, with an interval of 10 seconds between each narrative, so that it could later be presented to the judges.

The 90 narratives were presented to the judges, from Speech 1 to Speech 90, together with a questionnaire for identifying and characterizing the participants, as well as the grade for indicating the degree of intelligibility. The judges had to listen to each narrative and indicate the intelligibility considering the speech alterations produced by each subject. The possible marks concerning intelligibility were 9: Insufficient (when few words were understood and the subject had difficulties in understanding the main topic of the message); Regular (when at least half of the words could be understood and the subject could understand the main topic of the message); and Good (when it was possible to understand almost every word and to understand the content of the message).

\section{Analysis}

Based on the assessment by the groups of judges, it was possible to get the Mode (Mo) of the 90 narratives and to establish the Mode of the assessments for each subject. In total, it was possible to obtain the Mode of the three narratives of the 30 subjects. There were times when it was not possible to have a Mode in the assessments among the judges, as well as for each narrative and for each subject.

Kappa Statistics was used to check the association among the variables, and Landis and Koch (1977) classification was used to check the degree of concordance, which was: no concordance $(<0.00)$; poor $(0.00-0.19)$; regular (0.20 - 0.39), moderate $(0.40-0.59)$; substantial $(0.60$ - 0.79); almost perfect (0.80 - 1.00).

\section{Results}

Table 1 presents the results related to the intelligibility assessed by the judges and the concordance among the groups of speech therapists, mothers, and laypeople.

We can see in Table 1 that the degree of concordance among the speech therapists to good and insufficient intelligibility was moderate. As to the judgments for regular intelligibility, this group presented regular concordance.

It was not possible to determine the Mode of two subjects $(6.7 \%)$ because the speech therapists did not reach a consensus on their assessments. The concordance to these subjects was poor (0.019) in this group.

As for the group of mothers, we could observe that there was no Mode in the assessment of five (16.7\%) subjects. The concordance to good and insufficient intelligibility was regular. The degree of concordance to regular intelligibility was poor (0.037) (Table1), just like to the subjects without Mode.

As for the group of laypeople, it was possible to see that there was no Mode in the assessment of three subjects. The concordance to good and low intelligibility was substantial in this group. Besides, the concordance to regular intelligibility was regular. The concordance to the subjects without Moda was poor (0.185) (Table 1) in this group.

Table 2 presents the concordances between the groups of judges (speech therapists $\mathrm{x}$ mothers, speech therapists $\mathrm{x}$ laypeople and mothers $\mathrm{x}$ laypeople) to the intelligibility.

It was possible to see that, between the speech therapists and the mothers, the concordance was substantial to the classification of the good intelligibility. As for the intelligibilities judged as regular or insufficient, the degree of concordance between the speech therapists and the mothers was regular, just like for the subjects without Mode, who had concordance between these groups.

As for the degree of concordance between the speech therapists and the laypeople (Table 2), the same was substantial for the good intelligibility, whereas for the insufficient intelligibility it was moderate, and for the regular intelligibility the degree of concordance was regular. There was no concordance (-0.087) between the speech therapists and the laypeople for the subjects without Mode (Table 2).

We observed that the degree of concordance between the mothers and the laypeople was almost perfect for the good speech intelligibility. The concordance between these groups was regular for the insufficient and the regular intelligibilities. There was no concordance between the mothers and the laypeople $(-0.143)$ for the subjects without Mode (Table 2). 
Table 3 presents the degree of concordance to intelligibility (insufficient, regular and good) among all the judges (speech therapists $\mathrm{x}$ mothers $\mathrm{x}$ laypeople).

We can see that the degree of concordance among all the groups of judges was substantial for the good intelligibility. Besides, the moderate concordance was established for the insufficient intelligibility. As for the regular speech intelligibility, the concordance among the groups of judges was regular. For the subjects without Mode there was no concordance (-0.012) to speech intelligibility among the judges.

\section{Discussion}

There was more tolerance concerning the assessment of the subjects' narratives by the speech therapists, if compared to the assessment by the mothers and by the laypeople. The degree of concordance to intelligibility among the speech therapists was probably due to their experience and knowledge of speech disorder 4.

Based on the assessments by the speech therapists for speech intelligibility, the results presented in this research are not similar to those found in other research 9 done with speech therapy students and speech therapists as judges. The authors found that most subjects were classified by the judges as having good speech intelligibility, followed by regular and, at last, insufficient intelligibility.

We observed that there was a higher concordance among the groups of judges in relation to the extremes of the possibilities of assessment (i.e. good and insufficient intelligibility), which demonstrates that it is easier to identify and assess the subjects with these intelligibilities. In addition, we found that the degree of concordance was greater higher the laypeople than in the other groups (substantial) to good and insufficient intelligibility. For all the groups of judges the degree of concordance to the subjects without Mode was poor.

The fact that the concordance to intelligibility between the assessments by the speech therapists and by the mothers was substantial or regular can be justified by references that point out that the same pattern becomes familiar when the listener gets used to it 15 , or, besides, that experience with speech disorder may affect intelligibility 4 . This would explain the concordances among the groups,
TABLE 1. Intelligibility (I) of the subjects and the concordance, according to the assessment by the groups of judges.

\begin{tabular}{llllllllll}
\hline & \multicolumn{3}{c}{ Speech Therapists } & \multicolumn{3}{c}{ Mothers } & \multicolumn{4}{c}{ Laypeople } \\
& $\%$ & $\mathrm{n}$ & $\mathrm{c}$ & $\%$ & $\mathrm{n}$ & $\mathrm{c}$ & $\%$ & $\mathrm{n}$ & $\mathrm{c}$ \\
\hline Insufficient & 13.3 & 4 & 0.521 & 20.0 & 6 & 0.269 & 30.0 & 9 & 0.638 \\
Regular & 46.7 & 14 & 0.233 & 33.3 & 10 & 0.081 & 36.7 & 11 & 0.303 \\
Good & 33.3 & 10 & 0.561 & 30.0 & 9 & 0.342 & 23.3 & 7 & 0.665 \\
\hline
\end{tabular}

Legend: c: concordance.

TABLE 2. Degree of concordance of the intelligibility (I) among the groups of judges.

\begin{tabular}{lllll}
\hline & $\begin{array}{l}\text { Speech Therapists } \\
x \text { Mothers }\end{array}$ & $\begin{array}{l}\text { Speech Therapists } \\
\text { Laypeople }\end{array}$ & $\begin{array}{l}\text { Mothers } \\
\text { Laypeople }\end{array}$ & $x$ \\
\hline Insufficient & 0.286 & 0.528 & 0.386 \\
Regular & 0.318 & 0.253 & 0.341 \\
Good & 0.769 & 0.757 & 0.831 \\
\hline
\end{tabular}

TABLE 3. General degree of concordance among the judges for intelligibility (I).

\begin{tabular}{ll}
\hline Variable & Judges \\
\hline Insufficient & 0.4 \\
Regular & 0.299 \\
Good & 0.784 \\
\hline
\end{tabular}

as both the speech therapists and the mothers in this research have contact and experience with speech disorder.

It was possible to observe the almost perfect concordance $(0.831)$ for the assessment of the good intelligibility only among the mothers and the laypeople.

In Table 3 we could see that the concordance among the speech therapists, the mothers and the laypeople was greater (substantial) for the assessment of the good intelligibility (0.84), which shows that it may be easier to assess intelligibility in its extremes. As for the regular speech intelligibility there was higher concordance (regular 0.299), which demonstrates the higher discrepancy in the assessments of the intermediate possibilities of classification. 


\section{Conclusions}

It was possible to conclude that the regular concept was the most used by all the groups in their assessments. We found that the degree of concordance among the groups was higher for the speech intelligibility judged as good, probably because of the fact that the narratives were more easily understood by the judges.

Therefore, it is suggested that intelligibility assessments are more easily done by the judges when it is in one of the extremes of assessment (i.e. good and insufficient), whereas it is more difficult to judge and classify the regular intelligibility.

\section{References}

1. Nicolosi L, Harryman K, Kresheck J. Terminology of communication disorders. Baltimore: Williams \& Wilkins; 1989.

2. Hodson B, Paden E. Targeting intelligible speech: a phonological approach to remediation. San Diego: CollegeHill Press; 1983.

3. Gordon-Brannan M. Assessing intelligibility: children's expressive phonologies. Topics in Language Disorders. 1994;14(2):17-25.

4. Yavas M, Lamprecht RR. Os processos e a inteligibilidade na fonologia com desvios. In M Yavas. Desvios fonológicos em crianças: teoria, pesquisa e tratamento. Porto Alegre: Mercado Aberto; 1990.

5. Svirsky MA, Sloan RB, Caldwell M, Miyamoto RT. Speech intelligibility of prelingually deaf children with multichannel cochlear implants. Annals of Otology, Rhinology \& Laryngology. 2000;109:23-125.

6. Wertzner H, Pagan L, Galea D, Papp A. Características fonológicas de crianças com transtorno fonológico com e sem histórico de otite média. Revista da Sociedade Brasileira de Fonoaudiologia. 2007;12:41-7.

7. Wertzner H, Amaro L, Galea D. Phonological performance measured by speech severity indices compared with correlated factors. São Paulo Medical Journal. 2007; 125:309-14.
8. Gordon-Brannan M, Hodson B. Intelligibility severity measurements of prekinder. American Journal of SpeechLanguage Patholoy. 2000;9:141-50.

9. Wertzner H, Papp A, Amaro L, Galea D. Relação entre processos fonológicos e classificação perceptiva de inteligibilidade de fala no transtorno fonológico. Revista da Sociedade Brasileira de Fonoaudiologia. 2005;10(4):193200

10. Klein E, Flint C. Measurement of Intelligibility in disordered speech. language, speech and hearing services in schools. 2006;37:191-9.

11. Andrade C, Befi-Lopes D, Fernandes F, Wertzner H. ABFW: Teste de linguagem infantil nas áreas de fonologia, vocabulário, fluência e pragmática. São Paulo: Pró-Fono; 2000 .

12. Bernhardt B. The application of nonlinear phonological theory to intervention with one phonologically disorders child. Clinical Linguistics \& Phonetics. 1992;6(1-2):123-45.

13. Shriberg LD, Kwiatkowski J. Phonological disorders I: a diagnostic classification system. Journal of speech and hearing disorders. 1982a;47:226-41.

14. Almeida Z. Nova Dimensão em Produção de Textos. Belo Horizonte: Dimensão; 1993.

15. Shriberg LD, Kwiatkowski J. Phonological disorders III: A procedure for assessing severity of involvement. Journal of speech and hearing disorders. 1982b Aug;47: 256-70. 